\title{
Ringer-lactate solution as a priming fluid for the disc oxygenator
}

\author{
C. D. G. EVANS-PROSSER ${ }^{1}, G$. H. SMITH, AND \\ D. S. ROBERTSON \\ From Sheffield Cardio-Thoracic Unit, City General Hospital, Sheffield
}

Gadboys, Slonim, and Litwak (1962) reported what is now known as the homologous blood syndrome, which stimulated work on a substitute for blood in open-heart surgery, especially for the priming of the heart-lung machine.

The homologous blood syndrome was noted in experimental animals and consisted of hypotension on commencing cardiopulmonary bypass, with early thrombocytopenia, leucopenia, sequestration of blood elements, and subsequent pulmonary and renal problems. Gadboys et al. concluded that the changes were consistent with antigen-antibody reactions other than those due to $\mathrm{ABO}$ and $\mathrm{Rh}$ incompatibilities.

An obvious substitute was a colloid, such as a low molecular weight dextran (rheomacrodex) (Long, Sanchez, Varco, and Lillehei, 1961 ; Raison, 1962). Others have described using electrolyte solutions as partial primes and also as total non-blood primes.

Neptune, Bougas, and Panico (1961) reported the use of physiological saline; Zuhdi, McCollough, Carey, and Greer (1961), Cooley, Beall, and Grondin (1962), and Zuhdi, Carey, Sheldon, and Greer (1964) used 5\% dextrose in water, but as this was physiologically hypotonic, Linder, Sakai, and Paton (1964) attempted to improve the solution by using varying concentrations of saline rather than water. They found that $5 \%$ dextrose in $0.22 \%$ saline gave the best results.

Neville, Faber, and Peacock (1964a) showed that Ringer-lactate solution (Hartmann's solution) caused minimal disturbances of acid/base and electrolyte homoeostasis and seemed to be the most physiologically acceptable priming fluid available.

Total non-blood priming has required heartlung machines with reasonably small priming volumes, and this has discouraged the use of this

'Present address : St. Thomas' Hospital, London S.E.1 technique with the disc type of oxygenator, though Neville et al. (1964a) used the Kay-Cross oxygenator. Before changing to the RyggKvysgaard disposable oxygenator experience was gained with haemodilution using the Guy's-Ross heart-lung machine with disc oxygenators, and this paper aims to show how practical, satisfactory, and economical this technique has proved to be.

\section{TECHNIQUE}

Twenty-two consecutive patients who were undergoing procedures requiring cardiopulmonary bypass were studied. Their ages ranged from 7 to 49 years, and body weights from 21 to $75 \mathrm{~kg}$. Each patient received suitable doses of omnopon and scopolamine as premedication. Anaesthesia was induced with thiopentone $(2.5 \%)$ and was maintained with nitrous oxide and oxygen, and tubocurarine. Oxygen containing $0.5 \%$ halothane was fed into the oxygenator, and during total body perfusion the lungs were kept inflated with $100 \%$ oxygen.

The Guy's-Ross rotating disc oxygenator was used (Ross, 1960). This requires 2 litres of priming fluid for flows up to 2.5 litres/minute and 3 litres when an additional oxygenator was added, allowing flows up to 4 litres/minute. Acid-citrate-dextrose (A.C.D.) blood was used in preference to fresh blood both in the oxygenator, when necessary, and for direct intravenous infusion throughout the surgery. Theoretically, blood which is four to five days old is desirable in order to minimize the body reactions due to white cells and platelets.

Haemodilution was carried out with Ringer-lactate solution, with the addition of $20 \mathrm{mEq}$ sodium bicarbonate per litre of priming fluid in those patients who had a total non-blood prime. The average $p \mathrm{H}$ of Ringer-lactate is 6.5, and, in the absence of any blood, it was found necessary to counteract this with the bicarbonate (see Discussion). The degree of haemodilution was based on the estimated blood volume and the patient's haematocrit. The most accurate figure for estimating the blood volume proved 
to be $65 \mathrm{ml} . / \mathrm{kg}$. body weight (Wasserman, Yoh, and Rashkoff, 1951). The volume of Ringer-lactate used in the prime was calculated to bring the packed cell volume (P.C.V.) to a figure of between 20 and $24 \%$. Initially, the dilution used led to figures above this value, but the simplicity and safety of the technique led to increasing degrees of haemodilution (Table I) until. with suitably sized patients. a complete pump prime with Ringer-lactate was possible.

The patients were fully heparinized with $3 \mathrm{mg} . / \mathrm{kg}$. body weight and, in order to prevent dilution of heparin during perfusion, heparin was also added to the pump at the time of priming $(30 \mathrm{mg}$./litre).

The perfusion was started on a partial basis using a small flow initially-not more than $25 \%$ of estimated full flow until adequate mixing had occurred or until cooling was sufficient, if this was necessary. Full flows were based on a flow of 2.4 litres $/ \mathrm{m} .^{2}$ body surface at normal body temperature.

An estimate of P.C.V.. by the microhaematocrit method. was carried out after 10 minutes, and this figure was always the lowest that was recorded, suggesting that adequate mixing had occurred within this period. The patient was initially perfused with a positive fluid balance of about $200 \mathrm{ml}$., and this was increased during perfusion to about 1 litre after an hour.

Arterial blood pressure was often low, and figures of $20 \mathrm{~mm}$. Hg were not unusual during total perfusion. As soon as perfusion ended, the patient's red cell mass was restored to normal by infusing the fluid remaining in the pump. When only a partial nonblood prime was used. the volume of fluid infused was 1,000 to $1,800 \mathrm{ml}$., depending on calculations based on the patient's estimated blood volume and P.C.V. and on the P.C.V. of the perfusate at the end of bypass. Where no blood was used in the prime, the full contents of the extracorporeal circuit were returned to the patient. This was as much as 3,000 $\mathrm{ml}$. when the double oxygenator was used.

The patient's blood volume was raised by the infusion of volumes of $200 \mathrm{ml}$., and a continuous record of the central venous pressure was available. This showed a small rise following each $200 \mathrm{ml}$., which settled within two minutes. The next $200 \mathrm{ml}$. was then given. In this way the full volume could be given within 20 minutes, and the venous pressure at this point was usually little above normal.

Heparin was reversed. at the end of bypass. with protamine in a dosage of $4 \mathrm{mg}$. $/ \mathrm{kg}$. body weight, no account being taken of the heparin initially put in the pump. A heparin-protamine titration was carried out 20 minutes after the protamine had been given, and suitable adjustment was made if necessary.

In the post-operative period, apart from blood, only $5 \%$ dextrose in water was given by intravenous infusion. This was discontinued as soon as possible. Loss of blood was measured during and after operation. Any loss in the preperfusion period was replaced with A.C.D. blood before perfusion to obviate any further reduction in P.C.V. during the perfusion.

\section{INVESTIGATIONS}

Before operation the plasma urea and electrolytes, full blood count, bleeding and clotting times, prothrombin time, plasma fibrinogen, P.C.V., and plasmafree haemoglobin (P.F.Hb) were measured. A 24-hour specimen of urine was collected and examined.

At the start of the operation a urinary catheter was passed and the urinary output was measured hourly for 24 hours. During this time, the excretion of urea and electrolytes was measured at eight-hourly intervals. In the succeeding two days. 24-hour specimens were similarly examined.

The P.C.V., Hb, and P.F.Hb were measured at 20minute intervals during perfusion, one and three hours after perfusion, and on the next two days. Plasma electrolytes were measured one hour after perfusion and on the next two days.

At the end of perfusion the arterial $p \mathrm{H}, \mathrm{PCO}_{2}$, and standard bicarbonate were measured by the Astrup technique (Andersen, Engel, Jørgensen, and Astrup. 1960). When necessary, sodium bicarbonate was then given, a level of $20 \mathrm{mEq} / \mathrm{l}$. being regarded as a definite indication.

\section{RESULTS}

These are summarized in Table I. All 22 patients survived and left hospital, seven of them having had a total non-blood prime.

The P.C.V. fell to its lowest level within 10 minutes of the start of perfusion, and then rose from $1 \%$ to $6 \%$ during the remainder of the perfusion. This rise was not related to the length of perfusion. Within one hour of the end of perfusion, the P.C.V. had returned to within normal limits. Haemoglobin estimations provided a parallel series of results. Owing to technical $\underset{x}{x}$ difficulties, only five patients had estimations of $\frac{0}{3}$ P.F.Hb. Haemolysis reached a maximum towards the end of perfusion, and the highest figure recorded was $300 \mathrm{mg}$. $/ 100 \mathrm{ml}$. This soon fell and approached normal levels after two days.

Three patients developed petechiae post- $\rightarrow$ operatively.

At the end of perfusion, only four patients showed a base deficit sufficient to require sodium bicarbonate.

Plasma sodium and chloride showed a normal $\underset{\omega}{N}$ post-operative fall and remained within normal limits. The plasma potassium, however, fell below $4 \mathrm{mEq} / 1$. in seven patients within 24 hours, and $\Phi$ in 11 patients within 48 hours. This is the reverse $?$ of that expected in the metabolic response to $T$ trauma (Le Quesne, 1959).

Within 20 minutes of the end of perfusion a volume of perfusion fluid varying from $825 \mathrm{ml}$. Ф (case 12) to $3,000 \mathrm{ml}$. (case 10) was returned to 
T A B LE I

RESULTS IN 22 PATIENTS USING RINGER-LACTATE SOLUTION IN THE PRIMING FLUID

\begin{tabular}{|c|c|c|c|c|c|c|c|c|c|c|c|c|}
\hline \multirow{3}{*}{ Case } & \multirow{3}{*}{ Sex } & \multirow{3}{*}{$\begin{array}{c}\text { Age } \\
\text { (yrs) }\end{array}$} & \multirow{3}{*}{$\begin{array}{c}\text { Weight } \\
\text { (kg.) }\end{array}$} & \multirow{3}{*}{$\begin{array}{c}\text { Surface } \\
\text { Area } \\
\left(\mathrm{m} .{ }^{2}\right)\end{array}$} & \multirow{3}{*}{ Operative Procedure } & \multirow{3}{*}{$\begin{array}{l}\text { Per- } \\
\text { fusion } \\
\text { (min.) }\end{array}$} & \multirow{3}{*}{$\begin{array}{l}\text { Haemo- } \\
\text { dilution } \\
(\mathrm{ml} . / \mathrm{kg} .)\end{array}$} & \multirow{3}{*}{$\begin{array}{l}\text { Lowest } \\
\text { P.C.V. } \\
(\%)\end{array}$} & \multirow{2}{*}{\multicolumn{2}{|c|}{$\begin{array}{l}\text { Lowest } \\
\text { Temp. } \\
\text { (o C.) }\end{array}$}} & \multicolumn{2}{|c|}{ Priming Fluid } \\
\hline & & & & & & & & & & & \multirow{2}{*}{$\begin{array}{c}\text { Ringer- } \\
\text { lactate } \\
\text { (ml.) }\end{array}$} & \multirow{2}{*}{$\begin{array}{l}\text { A.C.D. } \\
\text { Blood } \\
\text { (ml.) }\end{array}$} \\
\hline & & & & & & & & & Oesoph. & Pharyn. & & \\
\hline $\begin{array}{l}1 \\
2 \\
3 \\
4 \\
5 \\
6\end{array}$ & $\begin{array}{c}\mathbf{M} \\
\mathbf{M} \\
\mathbf{F} \\
\mathbf{F} \\
\mathbf{F}\end{array}$ & $\begin{array}{l}12 \\
26 \\
49 \\
36 \\
10 \\
17\end{array}$ & $\begin{array}{l}54 \\
69 \\
63 \\
51 \\
35 \\
60\end{array}$ & $\begin{array}{l}1 \cdot 5 \\
1.9 \\
1.7 \\
1 \cdot 5 \\
1.2 \\
1.7\end{array}$ & $\begin{array}{l}\text { Aortic valvotomy (subvalvar) } \\
\text { Repair A.S.D. (secundum) } \\
\text { Aortic valvotomy } \\
\text { Aortic valvotomy } \\
\text { Pulmonary valvotomy } \\
\text { Pulmonary valvotomy. Repair }\end{array}$ & $\begin{array}{r}54 \\
39 \\
108 \\
78 \\
75\end{array}$ & $\begin{array}{l}37 \\
29 \\
36 \\
39 \\
43\end{array}$ & $\begin{array}{l}30 \\
33 \\
25 \\
25 \\
25\end{array}$ & $\begin{array}{l}28 \\
33 \\
24 \\
25 \cdot 5 \\
29\end{array}$ & $\begin{array}{l}31 \\
33 \\
24 \cdot 5 \\
27 \\
32\end{array}$ & $\begin{array}{l}2,000 \\
2,000 \\
2,250 \\
2,000 \\
1,500\end{array}$ & $\begin{array}{r}1,080 \\
1,080 \\
1,080 \\
1,080 \\
540\end{array}$ \\
\hline $\begin{array}{r}7 \\
8 \\
9 \\
10\end{array}$ & $\begin{array}{c}\mathbf{M} \\
\mathbf{M} \\
\mathbf{F}\end{array}$ & $\begin{array}{r}14 \\
8 \\
10 \\
14\end{array}$ & $\begin{array}{l}31 \\
25 \\
38 \\
48\end{array}$ & $\begin{array}{l}1 \cdot 1 \\
1 \cdot 0 \\
1 \cdot 3 \\
1 \cdot 4\end{array}$ & $\begin{array}{l}\text { V.S.D. } \\
\text { Repair V.S.D. } \\
\text { Pulmonary valvotomy } \\
\text { Repair V.S.D. } \\
\text { Pulmonary valvotomy. Repair }\end{array}$ & $\begin{array}{r}115 \\
104 \\
74 \\
85\end{array}$ & $\begin{array}{l}41 \\
48 \\
60 \\
40\end{array}$ & $\begin{array}{l}28 \\
25 \\
28 \\
26\end{array}$ & $\begin{array}{l}26 \\
18 \cdot 5 \\
31 \\
22 \cdot 5\end{array}$ & $\begin{array}{l}28 \\
21 \\
32 \\
28\end{array}$ & $\begin{array}{l}2,500 \\
1,500 \\
1,500 \\
1,500\end{array}$ & $\begin{array}{l}540 \\
540 \\
540 \\
540\end{array}$ \\
\hline $\begin{array}{l}11 \\
12 \\
13 \\
14 \\
15 \\
16 \\
17 \\
18\end{array}$ & $\begin{array}{c}\mathbf{F} \\
\mathbf{M} \\
\mathbf{M} \\
\mathbf{F} \\
\mathbf{M} \\
\mathbf{M}\end{array}$ & $\begin{array}{r}16 \\
7 \\
10 \\
36 \\
35 \\
8 \\
7 \\
34\end{array}$ & $\begin{array}{l}42 \\
21 \\
37 \\
65 \\
45 \\
25 \\
21 \\
75\end{array}$ & $\begin{array}{l}1 \cdot 3 \\
0.9 \\
1 \cdot 2 \\
1.7 \\
1.4 \\
0 \cdot 9 \\
0 \cdot 8 \\
2 \cdot 0\end{array}$ & $\begin{array}{l}\text { V.S.D. } \\
\text { Repair V.S.D. } \\
\text { Aortic valvotomy } \\
\text { Repair V.S.D. } \\
\text { Repair A.S.D. (secundum) } \\
\text { Repair A.S.D. (secundum) } \\
\text { Repair V.S.D. } \\
\text { Repair A.S.D. (secundum) } \\
\text { Repair A.S.D. and I.V.C. drain- }\end{array}$ & $\begin{array}{l}75 \\
60 \\
55 \\
49 \\
24 \\
26 \\
85 \\
24\end{array}$ & $\begin{array}{l}62 \\
47 \\
60 \\
54 \\
46 \\
55 \\
60 \\
47\end{array}$ & $\begin{array}{l}22 \\
22 \\
26 \\
22 \\
22 \\
28 \\
24 \\
27\end{array}$ & $\begin{array}{l}21 \cdot 5 \\
28 \cdot 5 \\
33 \\
34 \\
35 \\
35 \\
24 \\
35\end{array}$ & $\begin{array}{l}27 \\
30 \\
34 \\
35 \\
35 \\
36 \\
27 \cdot 5 \\
35\end{array}$ & $\begin{array}{l}3,000 \\
2,000 \\
1,250 \\
2,000 \\
3,000 \\
2,500 \\
1,500 \\
1,000\end{array}$ & $\begin{array}{r}0 \\
0 \\
1,080 \\
0 \\
0 \\
540 \\
540 \\
1,080\end{array}$ \\
\hline $\begin{array}{l}19 \\
20\end{array}$ & $\begin{array}{l}\mathbf{M} \\
\mathbf{M}\end{array}$ & $\begin{array}{r}23 \\
8\end{array}$ & $\begin{array}{l}63 \\
26\end{array}$ & $\begin{array}{l}1.7 \\
0.9\end{array}$ & $\begin{array}{l}\text { ing into L.A. } \\
\text { Repair A.S.D. (secundum) } \\
\text { Repair V.S.D. and pulmonary }\end{array}$ & $\begin{array}{l}76 \\
30\end{array}$ & $\begin{array}{l}40 \\
48\end{array}$ & $\begin{array}{l}32 \\
28\end{array}$ & $\begin{array}{l}33 \\
34 \cdot 5\end{array}$ & $\begin{array}{l}34 \\
35\end{array}$ & $\begin{array}{l}3,000 \\
3,000\end{array}$ & $\begin{array}{l}\mathbf{0} \\
\mathbf{0}\end{array}$ \\
\hline $\begin{array}{l}21 \\
22\end{array}$ & $\underset{\mathbf{M}}{\mathbf{F}}$ & $\begin{array}{r}8 \\
18\end{array}$ & $\begin{array}{l}24 \\
72\end{array}$ & $1 \cdot 0$ & $\begin{array}{l}\text { valvotomy } \\
\text { Repair V.S.D. } \\
\text { Repair A.S.D. (sinus venosus) }\end{array}$ & $\begin{array}{l}56 \\
46 \\
70\end{array}$ & $\begin{array}{l}60 \\
62 \\
42\end{array}$ & $\begin{array}{l}23 \\
28 \\
26\end{array}$ & $\begin{array}{l}35 \\
26 \\
29\end{array}$ & $\begin{array}{l}35 \cdot 5 \\
30 \\
31\end{array}$ & $\begin{array}{l}1,500 \\
1,500 \\
3,000\end{array}$ & $\begin{array}{r}540 \\
540 \\
0\end{array}$ \\
\hline
\end{tabular}

the patient. The circulation, as judged by central venous and arterial pressures and right atrial filling, was not embarrassed.

Urine production was very low during operation and did not reach a maximum until between 48 and 72 hours afterwards. Thus the average urine flow for the 22 patients was $13.5 \mathrm{ml} . / \mathrm{kg}$. in the first 24 hours, $33.5 \mathrm{ml} / \mathrm{kg}$. in the second 24 hours, and $52 \mathrm{ml} . / \mathrm{kg}$. in the third 24 hours.

The blood loss during and after operation in the first 14 patients is shown in Fig. 1. Out of the 14 patients, six had a loss of less than 1 litre $/ \mathrm{m} .{ }^{2}$ body surface area. In Table II the blood loss in 109 previous cases, with whole blood primes, is compared with all 22 cases.

CASE 3 A woman aged 49 years underwent aortic valvotomy. Before operation the $\mathrm{Hb}$ was $13 \mathrm{~g} . / 100$ ml., P.C.V. $44 \%$, and plasma sodium Na+ $144 \mathrm{mEq} / 1$, potassium $\mathrm{K}+5 \cdot 1 \mathrm{mEq} / \mathrm{l}$, and chloride $\mathrm{Cl}+102$ $\mathrm{mEq} / \mathrm{l}$. Ringer-lactate solution $(36 \mathrm{ml} . / \mathrm{kg}$.) $2.250 \mathrm{ml}$., and A.C.D. blood, $1,080 \mathrm{ml}$, were used as the priming fiuid.

Perfusion lasted 108 minutes, with a total perfusion of 37 minutes and hypothermia to $24.5^{\circ} \mathrm{C}$. pharynx ( $24^{\circ}$ C. oesophagus). The P.C.V. fell to $22 \%$ after 10 minutes' perfusion, then rose to $25 \%$ after 30 minutes, and remained steady for the rest of the perfusion. Maximum flow was 1.5 litres/minute, at $24.5^{\circ}$ C., and $1,800 \mathrm{ml}$. of fluid was returned at the end of perfusion to the patient. Arterial pressure varied from 35 to $60 \mathrm{~mm}$. $\mathrm{Hg}$ during the perfusion, and pupil size from 3 to $6 \mathrm{~mm}$. in diameter.

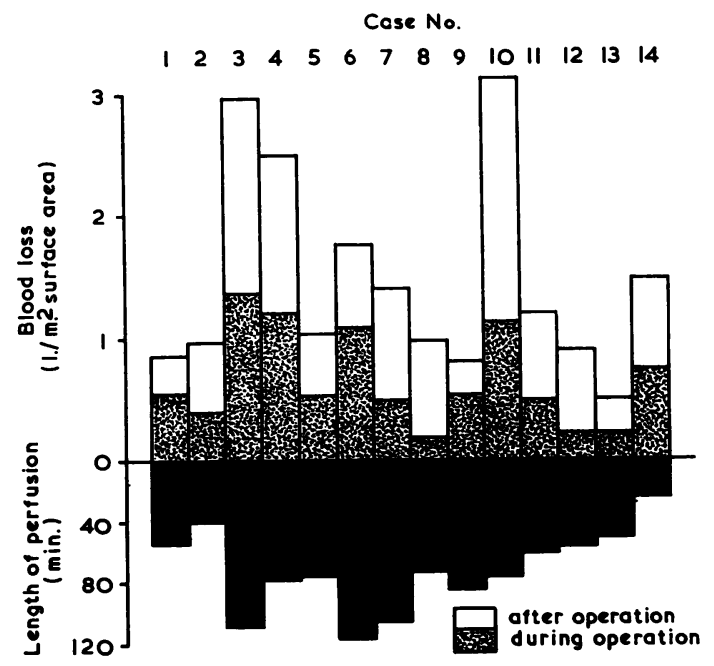

FIG. 1. Blood loss in 14 patients using Ringer-lactate perfusion.

T A B L E I I

BLOOD LOSS IN 22 CASES WITH HAEMODILUTION COMPARED WITH 109 PREVIOUS CASES WITH WHOLE-BLOOD PRIMES

\begin{tabular}{c|c|c|c|c}
\hline \multicolumn{1}{c|}{ Cases } & No. & $\begin{array}{c}\text { Loss in } \\
\text { Theatre } \\
\left(1 . / \mathbf{m}^{2}\right)\end{array}$ & $\begin{array}{c}\text { Post-op. } \\
\text { Loss } \\
\left(1 . / \mathrm{m}^{2}\right)\end{array}$ & $\begin{array}{c}\text { Total } \\
\text { Loss } \\
\left(1 . / \mathrm{m}^{2}\right)\end{array}$ \\
\hline $\begin{array}{l}\text { Present } \\
\text { Previous }\end{array}$ & 22 & $\begin{array}{l}0.67 \\
0.81\end{array}$ & $\begin{array}{l}0.83 \\
1.29\end{array}$ & $\begin{array}{c}1.5 \\
2.1\end{array}$ \\
\hline
\end{tabular}




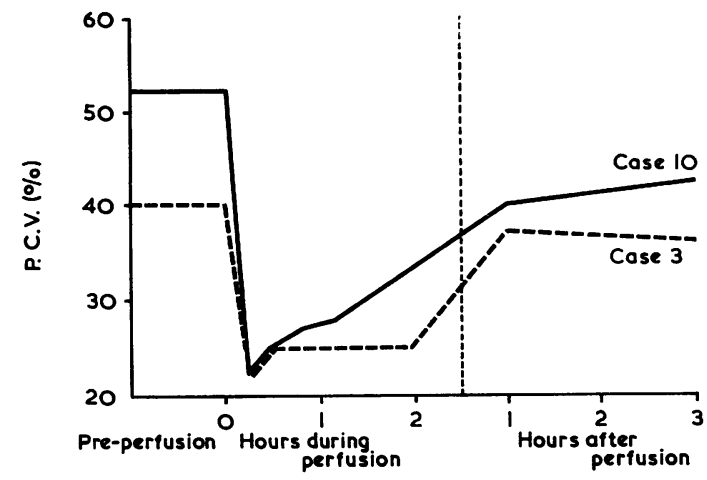

FIG. 2. Changes in P.C.V. in cases 3 and 10 during perfusion.

Changes in P.C.V. are shown in Fig. 2, which demonstrates the rapid return to normal in the first hour after perfusion. At the end of perfusion, the arterial blood $p \mathrm{H}$ was 7.58, $\mathrm{PCO}_{2} 28 \mathrm{~mm}$. $\mathrm{Hg}$, and standard bicarbonate $27 \mathrm{mEq} / 1$. Plasma sodium fell from $137 \mathrm{mEq} / 1$. one hour after perfusion to $120 \mathrm{mEq} / 1$. on the second post-operative day; $\mathrm{K}+$ from 4.2 to $3.3 \mathrm{mEq} / 1$. and $\mathrm{Cl}^{-}$from 100 to $90 \mathrm{mEq} / 1$. Urine flow was $400 \mathrm{ml}$. in the first 24 hours, $900 \mathrm{ml}$. in the next 24 hours, and $1,700 \mathrm{ml}$. in the third 24 hours following perfusion.

In view of her poor pre-operative general condition, and following a moderately prolonged perfusion, an elective tracheostomy was performed at the end of the operation. There were no respiratory complications, and she was discharged on the eighteenth postoperative day.

CASE 10 A girl aged 14 years, who had had a previous pulmonary valvotomy, underwent closure of a ventricular septal defect and relief of pulmonary infundibular stenosis. Before operation her $\mathrm{Hb}$ was 17 g./100 ml., P.C.V. 52\%, and plasma $\mathrm{Na}+141$ $\mathrm{mEq} / 1$., $\mathrm{K}+4.4 \mathrm{mEq} / 1$., and $\mathrm{Cl}^{-} 108 \mathrm{mEq} / 1$. Three litres of Ringer-lactate solution $(62 \mathrm{ml} . / \mathrm{kg}$.) and 60 $\mathrm{mEq}$ sodium bicarbonate were used as the priming fluid.

Perfusion lasted 75 minutes, with a partial perfusion of 42 minutes and hypothermia to $27^{\circ} \mathrm{C}$. pharynx $\left(21.5^{\circ}\right.$ C. oesophagus). The P.C.V. fell to $22 \%$ after 10 minutes' perfusion, then rose slowly to $28 \%$ by the end of perfusion. Maximum flow was $2 \cdot 2$ litres per minute at $27^{\circ} \mathrm{C}$., and 3 litres of fluid were returned at the end of the perfusion to the patient. Arterial pressure varied from 40 to $45 \mathrm{~mm}$. Hg during total perfusion, and pupil size from 3 to $6 \mathrm{~mm}$. diameter. During a phase of total perfusion, the maximum flow obtainable fell to $500 \mathrm{ml}$. without obvious cause, but improved at once on partial rewarming.

Changes in P.C.V. are shown in Fig. 2 with a similar rise immediately following perfusion. At the end of perfusion, the arterial blood $p \mathrm{H}$ was 7.57,
$\mathrm{PCO}_{2} 15 \mathrm{~mm}$. $\mathrm{Hg}$, and standard bicarbonate $22.5 \mathrm{O}$ $\mathrm{mEq} / 1$. Plasma $\mathrm{Na}+$ fell from $138 \mathrm{mEq} / \mathrm{l}$. one hour $\overline{\bar{\sigma}}$ post-perfusion to $135 \mathrm{mEq} / \mathrm{l}$. on the second post- $\overline{\bar{S}}$ operative day; $\mathrm{K}+$ from 4.2 to $3.4 \mathrm{mEq} / 1$. and $\mathrm{Cl}^{-} \mathbb{\mathbb { D }}$ from 102 to $91 \mathrm{mEq} / 1$. Urine flow was $1,190 \mathrm{ml}$. in the first 24 hours, $1,500 \mathrm{ml}$. in the next 24 hours, and $\omega$ $2,300 \mathrm{ml}$. in the third 24 hours following perfusion. $\vec{\circ}$ Ventricular fibrillation occurred in the thirteenth hour $\rightarrow$ after operation but responded to external cardiac $\vec{\omega}$ massage and defibrillation. A branch of the right coronary artery had been inadvertently divided in $\overrightarrow{\vec{x}}$ this patient and may have resulted in some electrical iv instability of the heart. Otherwise recovery was rapid, and she was discharged on the fourteenth post- of operative day.

\section{COMPLICATIONS}

Two other patients developed post-operative complications. Case 5 required bronchoscopy 24 hours after operation for retention of sputum in the left main bronchus. Case 12 had two convulsions on the day after operation. Both patients subsequently made a normal recovery.

\section{DISCUSSION}

The use of non-blood fluids in the priming of the extracorporeal circulation has many theoretical disadvantages, such as the reduction in oxygencarrying capacity, with the danger of tissue hypoxia, dilution of the clotting factors, and electrolyte changes. In practice, these do not exist.

The volume of infused fluid, compared with that of the total body water, is small and therefore results in only a minimal dilution of the electrolytes. The distribution of this fluid throughout the body takes some time, and, during the first 30 minutes, most of it remains in the intravascular compartment.

Neville, Spinazzola, Banuchi, Scicchitano, and Peacock (1964) have described their experiences using dilutions of 32 to $52 \mathrm{ml}$. $/ \mathrm{kg}$. body weight, $\frac{D}{O}$ with flows of 45 to $50 \mathrm{ml}$. $/ \mathrm{kg}$./minute. Measurements confirmed that such a flow and dilution $N$ were adequate for supplying tissue oxygen demands and that there was minimal disturbance of clotting mechanisms and electrolyte concentrations. It was found that, using a total Ringerlactate prime, $33 \%$ of patients suffered a base deficit of 2 to $5.5 \mathrm{mEq} /$ litre. This led to the $\mathscr{\mathscr { C }}$ addition of $22 \mathrm{mEq}$ sodium bicarbonate to each litre of priming fluid.

Najafi, Neville, Banuchi, Peacock, and Meeks (1965) have shown that satisfactory results are $\frac{\rho}{\Phi}$ obtained in dogs with total Ringer-lactate primes producing haemodilutions up to $73 \mathrm{ml} . / \mathrm{kg}$. body 
weight, while Roe, Swenson, Hepps, and Bruns (1964) showed that a reduction of P.C.V. to 20 to $24 \%$ was well tolerated by humans.

The restoration of the patient's red cell mass to normal at the end of perfusion requires the infusion of a large volume of fluid, most of which must leave the circulation rapidly. Hence plasma expanders are not suitable for use as a total prime. Long et al. (1961) used low molecular weight dextran (L.M.W.D.) as a partial priming fluid to overcome the aggregation of red cells, and to increase the capillary perfusion, in the peripheral circulation. However, L.M.W.D. is not only retained in the circulation for at least four hours but also attracts an equal volume of fluid from the tissues. In addition, they found that more than $20 \mathrm{ml} . / \mathrm{kg}$. leads to derangement of the clotting mechanism. Thus it is unsuitable in a total prime.

During perfusion, when the circulating blood volume remained near normal limits, the P.C.V. rose slowly. This indicates either a small transfer of fluid from the vascular to the extravascular compartment or an increasing capillary perfusion secondary to the lowered viscosity. When the R.B.C. mass in the patient had been restored to normal, the P.C.V. of the circulating blood rose to pre-perfusion levels within one hour. This indicates a considerable shift of fluid into the extravascular compartment. Moreover, there is evidence that the infused fluid and electrolytes are not fully excreted until the third post-operative day. The urinary output in the 10 cases reported rose to $52 \mathrm{ml} . / \mathrm{kg}$. body weight on that day, and the concentration of electrolytes in the urine increased.

The plasma potassium fell from its preoperative value, and this was maximal on the first post-operative day. Haupt, Myers, Daly, and Birkhead (1964) found a similar fall. Barnard, Saunders, Eales, and Barnard (1966) have reported this to be due to a redistribution of potassium ions between the intra- and extra-cellular body compartments. It was thought likely that the redistribution was the cause of ventricular arrhythmias occurring after perfusion. Prevention of hyperventilation and of sodium bicarbonate excess could minimize this shift, as could the addition of $3 \%$ carbon dioxide to the gases in the oxygenator. It is important to prevent alkalosis during perfusion for this reason. During perfusion, high flow rates were easier to attain and maintain, although in one case (case 10) there was difficulty in obtaining adequate venous return.

The arterial pressure was often low during perfusion, and steady levels of $20 \mathrm{~mm}$. $\mathrm{Hg}$ were not unusual. The lowering of the blood viscosity must contribute to this and must improve the perfusion during hypothermia when blood viscosity normally increases. Evidence of adequate tissue perfusion at such pressures is provided by a normal pupil size during perfusion, by the early regain of consciousness, and by the absence of any degree of metabolic acidosis.

Difficulty was experienced in obtaining hypothermic cardiac arrest or ventricular fibrillation during perfusion. In case 7 , sinus rhythm persisted in spite of an oesophageal temperature of $18.5^{\circ} \mathrm{C}$. This observation was also made by Roe et al. (1964).

After operation, the patients usually recovered consciousness in the theatre, and their cooperation in the immediate post-operative period was good. The incidence of respiratory problems was reduced, and there was a noticeable improvement in the patients' colour when breathing air during the early post-operative period as compared with those who had had whole blood primes. It is realized that these impressions are of limited value and more evidence is being collected.

Previous authors have been impressed by the decreased blood loss despite the theoretical disadvantages of diluted clotting factors (Cooley et al., 1962; Roe et al., 1964). The decreased viscosity, in contrast, leads to less damage to the blood elements. The results in this series, though small, show that the blood loss was $30 \%$ less than in the earlier cases (Table II). Thus the haemodilution technique may lead to a saving of 3 litres of blood for priming the extracorporeal circuit and also one or two units of transfused blood per average patient.

\section{SUMMARY}

The use of Ringer-lactate solution as a non-blood prime for the extracorporeal circulation is described. Twenty-two cases in which this technique has been used are described, and the advantages and disadvantages are discussed. Ringer-lactate appears to be a satisfactory non-blood priming solution in dilutions up to $60 \mathrm{ml}$. $/ \mathrm{kg}$. body weight, and with a P.C.V. of not less than $20 \%$.

We thank Mr. D. G. Taylor, who operated on all the patients, for permission to publish these results and for his advice and encouragement. We should also like to thank the sisters and nursing staff of the City General Hospital, Royal Infirmary, and Children's Hospital, and Miss Norma Pinkney for secretarial assistance. The diagrams were prepared by $\mathrm{Mr}$. A. S. Foster, medical artist, and the photographic Department of the Royal Infirmary, Sheffield. 


\section{ADDENDUM}

Since recording these cases a further 18 patients have been operated on using this technique. nine of whom had total Ringer-lactate primes. The results support those reported above.

\section{REFERENCES}

Andersen, O. S., Engel, K., Jorgensen, K., and Astrup, P. (1960). A micro method for determination of $\mathrm{pH}$, carbon dioxide tension, base excess and standard bicarbonate in capillary blood. Scand. b. clin. Lab. Invest., 12, 172 .
J

Barnard, M. S., Saunders, S. J., Eales, L., and Barnard, C. N. (1966). Hypokalaemia during extracorporeal circulation. Lancet, 1, 240.

Cooley, D. A., Beall, A. C., and Grondin, P. (1962). Open-heart operations with disposable oxygenators, $5 \%$ dextrose prime, and normothermia. Surgery, 52, 713.

Gadboys, H. L., Slonim, R., and Litwak, R. S. (1962). Homologous blood syndrome; Preliminary observations on its relationship to clinical cardiopulmonary bypass. Ann. Surg., 156, 793.

Haupt, G. J., Myers, R. N., Daly, J. W., and Birkhead, N. C. (1964). Blood and urine electrolyte changes during open heart surgery using no-blood prime and mannitol. Trans. Amer. Soc. Artificial intern. Organs, 10, 38.

Le Quesne, L. P. (1959). In General Anaesthesia, ed. by F. T. Evans and C. Gray, Vol. 1, p. 468.

Linder, E., Sakai, Y., and Paton, B. P. (1964). Electrolyte changes during dilution perfusion. Arch. Surg., 88, 175.
Long, D. M., Sanchez, L., Varco, R. L., and Lillehei, C. W. (1961)음 The use of low molecular weight dextran and serum albumin as plasma expanders in extracorporeal circulation. Surgery, 50, 12 은

Najafi, H. Neville, W. E., Banuchi, F., Peacock, H., and Meeks, M. F $\stackrel{\mathscr{\mathcal { D }}}{\supset}$ (1965). Comparison of high- and low-volume hemodilution for $\vec{D}$ cardiopulmonary bypass. Ibid., 58, 989 .

Neptune, W. B., Bougas, J. A., and Panico, F. G. (1961). Open hearin surgery without the need for donor-blood priming in the pumpes oxygenator. New Engl. J. Med., 263, 111.

Neville, W. E., Faber, L. P., and Peacock, H. (1964a). Total prime of the disc oxygenator with Ringer's and Ringer's lactate solutionfor cardiopulmonary bypass. Dis. Chest, 45, 320.

- Spinazzola, A., Banuchi, F., Scicchitano, L. P., and Peacock, H. for total prime of the disc oxygenator during cardiopulmonary bypass. J. thorac. cardiovasc. Surg., 48, 101.

Raison, J. C. A. (1962). A clinical report of the use of low-molecularweight dextran in a rotating oxygenator. Thorax, 17, 338.

Roe, B. B., Swenson, E. E., Hepps, S. A., and Bruns, D. L. (1964) Total body perfusion in cardiac operations. Arch. Surg., 88, 128. T

Ross, D. N. (1960). Hypothermia and the heart-lung machine. Brit med. J., 2, 571 .

Wasserman, L. R., Yoh, T. F., and Rashkoff, I. A. (1951). Blood volume determination: comparison of T-1284 and $\mathrm{P}^{32}$ labeled redcell methods. J. Lab. clin. Med., 37, 342.

Zuhdi, N., McCollough, B., Carey, J., and Greer, A. (1961). Doublehelical reservoir heart lung machine. Arch. Surg., 82, 320.

- Carey, J., Sheldon, W., and Greer, A. (1964). Comparative merits and results of primes of blood and $5 \%$ dextrose in water for heart-lung machines: analysis of 250 patients. $J$. thorac cardiovasc. Surg., 47, 66. 